\title{
Investigation of the Relation between Core Muscle Strength, Durability and Reaction Performance for Swimmers
}

\author{
Türker Bıyıklı \\ Correspondence: Türker Bıyıklı, Nisantasi University Physical Education and Sports School, İstanbul, Turkey. \\ Received: October 2, 2018 \\ doi:10.11114/jets.v6i11.3667 \\ Accepted: October 26, $2018 \quad$ Online Published: October 29, 2018 \\ URL: https://doi.org/10.11114/jets.v6i11.3667
}

\begin{abstract}
Investigation of the relation between reaction time performances and core muscle strength and durability of the swimmers is aimed in the research. 21 elite male sportsmen with $21,92 \pm 5,03$ years of age average, 174,14 \pm 4,27 cm of length average and 75,02 $\pm 6,61 \mathrm{~kg}$ of body weight from College swimming team participate the research.

Right-left hands audio and visual reaction times and plank and side plank performance values of the sportsmen are received. The data achieved provides minimum and maximum values, average and standard deviation values. Moreover Pearson correlation test is applied to determine the relation between the variants. According to the findings of the research, medium-level positive relation is detected between right hand visual reactions and plank measurement values, and poor-level positive relation is detected between right hand audio reactions of the swimmers $(r=, 692, p<, 021 ; r=, 277$, $\mathrm{p}<, 039)$.

In conclusion, relation is detected between core muscle strength and durability and visual and audio right hand reaction time. It may be stated that development of core muscle strength and durability may improve reaction time.
\end{abstract}

Keywords: core strength, core durability, reaction, swimmers

\section{Introduction}

Core and stabilization are very important for a swimmer. Because all movement chain patterns start from the center and go outward.

The neuromusculoskeletal core of the human movement system (HMS) is defined by the structures that make up the lumbo-pelvic-hip complex (LPHC) (Arokoski at al, 2001; Kibler, Sciascia and Dome, 2006). An efficient core ensures optimal length-tension relationships of functional agonists and antagonists, which makes it possible for the HMS to maintain favorable force-couple relationships throughout the LPHC. Maintenance of optimum length-tension and force-couple relationships allows for optimum joint arthrokinematics in the LPHC during functional movements (Sahrmann, 2002). Core concept can be defined as complete muscle groups playing an influential role in force transitions in lower and upper extremity, supporting and covering spine and constituting the body. Strengthen core muscles is a critical factor for developing physical performance and dynamic core expediting returning to the site for being protected from sports injuries and for rehabilitation. For this reason, core exercise has become a method used for a common strength development in recent times. Movements in core exercise program include static or dynamic exercises (Richardson et al, 2002).

The core operates as an integrated functional unit enabling the entire LPHC to work synergistically to produce force concentrically, decelerate force eccentrically, and stabilize against abnormal compressive, torsional, and shear forces isometrically (Barr, Griggs and Cadby, 2005). In an efficient state, each structural component of the core distributes weight, absorbs force, and transfers ground reaction forces to maintain the athlete's center of mass over a constantly changing base of support. This neuromuscular efficiency of the core or LPHC is often referred to as core stability, but is more accurately described as LPHC stability comprised of local or intersegmental stability (Local Stabilization System), global stability (Global Stabilization System), and global mobility (Bergmark, 1989; McGill, 2002). This interdependent system needs to be appropriately trained to enable it to function efficiently during dynamic activities (Figure 1).

High-level sports performance requires functional strength, power, neuromuscular control, and muscular endurance in specific muscles. A well-designed integrated training program ensures that the body's stabilization system will function 
utilizing the developed strength, power, neuromuscular control, and muscular endurance of its prime movers. However, many athletes fail to develop the muscles required for optimal neuromuscular efficiency and stabilization of the LPHC (McGill, 2002; Richarson et al, 1999). If the extremity muscles are strong and the core is weak, there will be insufficient forces moving throughout the HMS for efficient movements (Carter et al, 2006).

A weak core is a fundamental problem inherent to inefficient movement that may lead to predictable patterns of injury (Hodges and Richardson, 1996; Nadler et al, 2002; O’Sullivan et al, 1997; Hewett Paterno and Myer, 2002, Nadler et al, 2002). A properly designed core training program, however, helps an athlete gain neuromuscular control, stability, muscle endurance, strength, and power of the core.

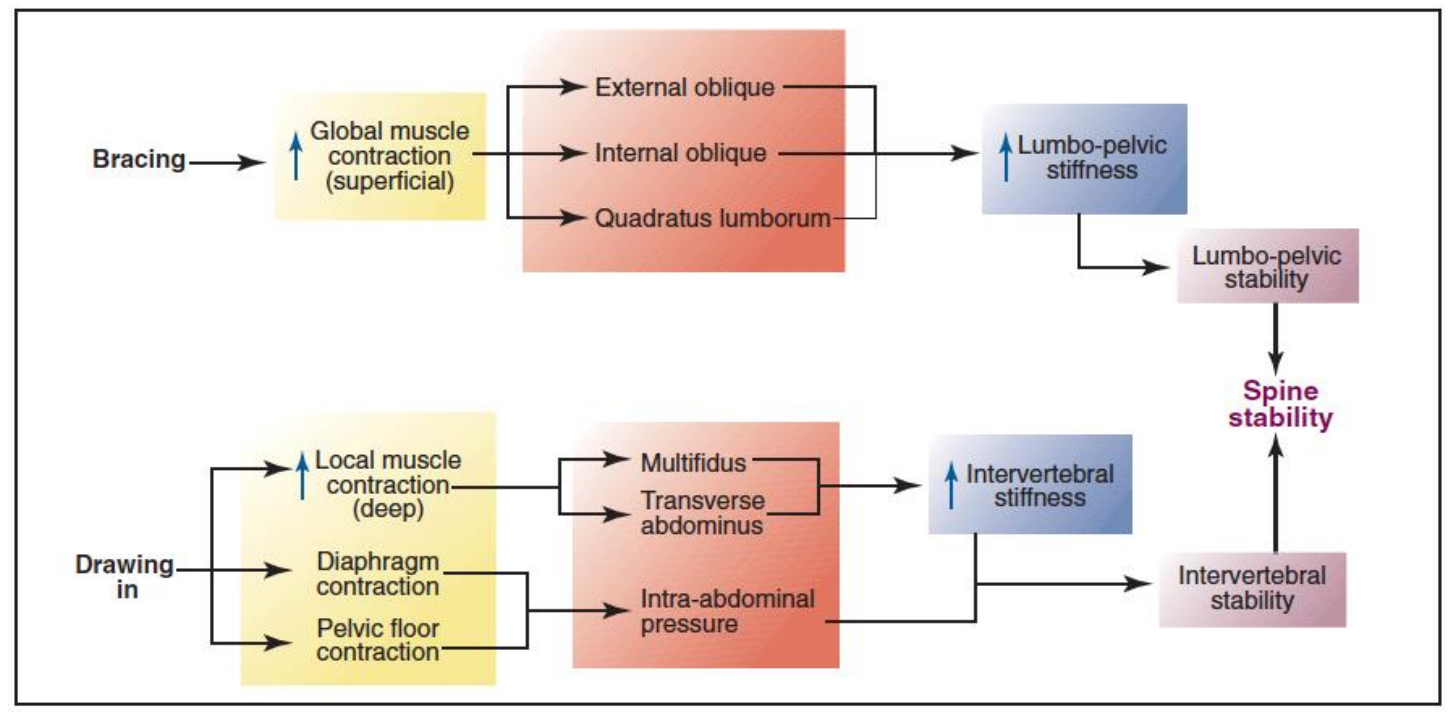

Figure 1. Optimal Spinal Stability

This integrated approach facilitates balanced muscular function of the entire HMS (Hirashima et al, 2007; Putnam, 1993). Greater neuromuscular control and stabilization provides a more biomechanically efficient position for the LPHC. This allows for optimum sequenced activation (sequential kinematics and kinetics) of body segments that place the extremities in the optimum position, at optimum velocity, and with optimum timing, to produce the desired athletic task (Putnam, 1993).

\subsection{Functional Anatomy of the Core}

To understand core training, the Sports Performance Professional must fully understand functional anatomy, core (LPHC) stabilization mechanisms, and normal force-couple relationships. A review of the key core musculature enables the Sports Performance Professional to understand functional anatomy and develop an integrated training program. The core musculature has been divided into the local stabilization system, global stabilization system, and the movement system. To maintain core stability, integrated neuromuscular control of the local, global, and movement system is required, ensuring sequential coordinated activation of all systems at the right time with the right amount of force.

\subsection{Core Stabilization Mechanisms}

The core (LPHC) is stabilized during functional movement by two primary systems: the thoracolumbar stabilization mechanism and the intra-abdominal pressure stabilization mechanism (McGill, 2002; Hodges, 199; Cholewicki, Juluru and McGill, 1999; Richardson et al, 2002).

The thoracolumbar fascia (TLF) stabilization mechanism is accomplished through a fascial network of noncontractile tissue that plays an essential role in the functional stability of the core and is divided into the posterior, anterior, and middle layers Although the TLF is noncontractile, it can be engaged dynamically because of the contractile tissue that attaches to it. The muscles that attach to the TLF include: the deep erector spinae, multifidus, transverse abdominus, internal oblique, gluteus maximus, latissimus dorsi, and quadratus lumborum (Newmann, 2002). The transverse abdominus and the internal oblique are particularly important for stabilization. They attach to the middle layer of the TLF via the lateral raphe and activation of both create a traction and tension force on the thoracolumbar fascia, which enhances the regional intersegmental stability in the core decreasing translational and rotational stress (Hodges, 1999; O’Sullivan, Twomey and Allison, 1998; Richardson et al, 2002).

The second stabilization mechanism involves the intra-abdominal pressure mechanism Increased intra-abdominal pressure mechanism decreases compressive forces in the core. The abdominal muscles contract against the viscera, 
pushing the viscera superiorly into the diaphragm and inferiorly into the pelvic floor. This increase in the intra-abdominal pressure results in elevation of the diaphragm and contraction of pelvic floor musculature while also assisting in providing intersegmental stabilization to the core (LPHC) (Hodges, 1999; Cholewicki et al, 1999; Cresswell, Oddsson and Thorstensson, 1994).

\section{Method}

21 elite male sportsmen with 21,92 $\pm 5,03$ years of age average, 174,14 $\pm 4,27 \mathrm{~cm}$ of length average and 75,02 $\pm 6,61 \mathrm{~kg}$ of body weight from College swimming team participate the research. The participants are informed about the training and measurements. The measurements are received in the sports hall of the College.

\subsection{Collection of Data}

Length and Body Weight: The lengths of the research sportsmen are measured by a meter made from metal in fixed 0,1 $\mathrm{cm}$ sensitivity. Body weights are measured by bare feet and with light clothes on them through a weighing machine with $0,1 \mathrm{~kg}$ sensitivity.

Reaction Test: Audio and visual reaction times are measured by using Newtest 1000 instrument. In terms of measuring reaction times, it is paid attention that the measurement place is noiseless and bright. 3 trials and 3 measurements after the test are made on the research sportsmen against noise and light stimulus. The best value of 3 measurements received is recorded in millisecond (ms) as the scores of the participants. The sportsmen are asked to use their both hands in terms of measuring audio and visual reaction times.

Plank: It is the protection of balance by making a straight line with the heels and the head on the elbows and feet as the body is a face down through the floor. The sportsmen get to plank position by the start order. They are warned in case of ruining the position (dropping the bottom low or lifting it up). The tests of 3 sportsmen, who are warned, are ended. The time of plank positions of the sportsmen are recorded in seconds (Boyac1 et al 2018).

Side Plank: The research sportsmen are asked to wait in side plank position as the elbows are under the shoulders and upper arm is vertical to the floor. They are warned in case of ruining the position. The tests of 3 sportsmen, who are warned, are ended. The time of side plank positions of the sportsmen are recorded in seconds.

\section{Statistical Analyses}

Descriptive statistics were performed on all data. Relationships between test variables were determined using multiple bivariate correlations, represented by the Pearson correlation coefficient. Statistical significance was set at p 0.05. SPSS 22.0 software was used for all analyses.

\section{Findings}

Table 1. Descriptive statistical table of the sportsmen

\begin{tabular}{lccccc}
\hline Variant & n & Min. & Max. & Ave. & Std. \\
\hline Age (year) & 21 & 18,00 & 25,00 & 21,92 & 5,03 \\
Length (cm) & 21 & 164,00 & 182,00 & 174,14 & 4,27 \\
Body Weight (kg) & 21 & 60,00 & 86,00 & 75,02 & 6,61 \\
\hline
\end{tabular}

Cm: Centimeter, Kg: Kilogram

Ages of the sportsmen participating in the research are detected as 21,92 $\pm 5,03$ years, their lengths are detected as $174,14 \pm 4,27 \mathrm{~cm}$ and their body weights are detected as $75,02 \pm 6,61 \mathrm{~kg}$.

Table 2. Reaction and core strength measurement table of the sportsmen

\begin{tabular}{lccccc}
\hline Variant & n & Min. & Max. & Ave. & Std. \\
\hline Visual Reaction Right Hand (msn) & 21 & 168,00 & 259,00 & 215,92 & 25,93 \\
Visual Reaction Left Hand (msn) & 21 & 184,00 & 300,00 & 212,33 & 34,50 \\
Audio Reaction Right Hand (msn) & 21 & 160,00 & 286,00 & 195,92 & 35,15 \\
Audio Reaction Right Hand (msn) & 21 & 152,00 & 259,00 & 198,45 & 36,58 \\
Plank (sn) & 21 & 78,12 & 129,20 & 99,65 & 24,35 \\
Side Plank (sn) & 21 & 131,45 & 182,88 & 159,75 & 28,83 \\
\hline
\end{tabular}


Table 3. Relation between reaction and core strengths of the sportsmen

\begin{tabular}{cccc}
\hline Variant & & Plank & Side Plank \\
\hline \multirow{2}{*}{ Visual Reaction Right Hand } & $\mathrm{r}$ &, 692 &, 528 \\
& $\mathrm{p}$ & $\mathbf{, 0 2 1}$ &, 256 \\
& $\mathrm{n}$ & 21 & 21 \\
\hline \multirow{2}{*}{ Visual Reaction Left Hand } & $\mathrm{r}$ &, 494 &, 213 \\
& $\mathrm{p}$ &, 201 &, 170 \\
\hline \multirow{2}{*}{ Audio Reaction Right Hand } & $\mathrm{n}$ & 21 &, 324 \\
& $\mathrm{r}$ &, 277 &, 201 \\
& $\mathrm{p}$ & $\mathbf{, 0 3 9}$ & 21 \\
\hline \multirow{2}{*}{ Audio Reaction Right Hand } & $\mathrm{n}$ & 21 &, 191 \\
& $\mathrm{r}$ &, 183 &, 149 \\
& $\mathrm{p}$ &, 107 & 21 \\
\hline
\end{tabular}

Investigating Table 3, medium-level positive relation is detected between right hand visual reactions and plank measurement values, and poor-level positive relation is detected between right hand audio reactions of the sportsmen $(\mathrm{r}=, 692, \mathrm{p}<, 021 ; \mathrm{r}=, 277, \mathrm{p}<, 039)$. No statistical relation is encountered between left hand visual and audio reaction and plank measurement and right-left hand visual and audio reaction tests and side plank measurements.

\section{Discussion and Conclusion}

Investigation of the relation between reaction times and core muscle strength and durability of the college swimming team sportsmen is aimed in the research. Visual reaction right hand of the sportsmen is detected as $215,92 \pm 25,93$, left hand is detected as $212,33 \pm 34,50$, audio reaction right hand is detected as $195,92 \pm 35,15$, audio reaction left hand is detected as $198,45 \pm 36,58$, plank is detected as $99,65 \pm 24,35$ and side plank is detected as $159,75 \pm 28,83$ (Table 2).

Reaction times may develop by regular training (Bompa 1998, Ozer 2007) as well as they are known to develop by age (Akgun 1988, Aslan 2016, Colakoglu 1986). Dundar (1996) states that reaction times may develop until 0.12 msn by trainings, Colakoglu et al. (1993) state that reaction times may be shortened by the physical trainings made for a long time.

It may be said that dominant hand reaction times of the swimmers are better compared to athletes though there is no statistically significant difference observed $(\mathrm{p}=0,06<0.05)$ between average of the athletes $(283,583 \mathrm{msn})$ and average of the swimmers $(243,16 \mathrm{msn})$ in terms of dominant hand reaction times in the research of Pulur et al. (2017), in which right-left hand and noise reaction times of the sportsmen from different branches are compared. Average of both hand reaction times is found as $288,94 \mathrm{msn}$ in terms of the swimmers. As a result of multiple comparisons $(\mathrm{p}=0,51>0,05)$, no significant difference is found between the branches. It is thought that achieving lower results compared to other branches are normal considering the fact that the swimmers with best averages use their both hands as per the sports they do although there is no significant difference between them. When reaction against noise times are observed, the averages of the swimmers are measured as $243,17 \mathrm{msn}$. It is observed that there is statistically significant difference between the fencers and swimmers $(\mathrm{p}=0,00<0,05)$. Duvan et al. (2010) detect that dominant hand visual reaction times of male fencers are $171,00 \pm 16,06 \mathrm{sec}$. as a result of the study they have conducted on the purpose of searching the effects of maximal overloading intensity of elite male and female fencers on visual reaction time. Di Russo et al. (2006) detect averages of reaction times of male fencers as $356,49 \pm 38,50 \mathrm{~ms}$ and averages of reaction times of male karate players as $399,00 \pm 72,50 \mathrm{~ms}$ in the study they have conducted on the sportsmen included in Spain fencing and karate National Team. Delignieres et al. (1994) detect resting reaction times of fencers as $270,35 \pm 25,49 \mathrm{~ms}$, resting reaction time values of the boxers as $273,64 \pm 35,56 \mathrm{msn}$, resting reaction time values of the tennis players as 251,36 $\pm 32,05 \mathrm{msn}$, resting reaction time values of the table tennis players as $324,46 \pm 72,41 \mathrm{msn}$ in the study they have conducted. Karagöz (2008) find visual reaction averages between 349,0 and 405,9 $\mathrm{msn}$ in the boys and between 312,4 and 430,2 msn in the girls in the study he/she has conducted with girl and boy tennis players at age 8-10. Aslan et al. (2013) find 0,383 and 0,277 msn results in two different groups.

Afyon and Boyacı (2016) aim at investigation of the effects of core trainings on the development of some motoric characteristics in the study they have conducted on the football players. They state that 8 weeks of core trainings to be applied in addition to the football trainings have contributions on the strength development of the football players. Bassett and Llyod (2011) state that development is provided in strength performances, plank positions and core regions in terms of elite gymnasts as a result of core training applications. Boyacı and Tutar (2018) detect that development of core muscle strength and durability is provided by Quad-Core (front plank, side plank and back plank) protocol they apply on the children in development period. Boyacı and Afyon (2017) find in the research they have conducted on child athletes that 12 weeks of core trainings cause development in plank performances. Santana (2005) find that core trainings applied on contestant male swimmers increase their strengths. Boyac1 et al. (2018) report that static and dynamic core trainings develop core muscle and durability of the sportsmen. 
When the related literature is investigated, it is specified by many researchers that core trainings have impacts on motoric characteristics and have contributions on sportive performance increase (Samson, 2005; Thomas, William, 2009; Jim et al., 2012; Atıc1, 2013; Afyon, 2014). However, no research related to the impact of core training on reaction time and investigating the relation between core muscle strength and durability and reaction time performance is encountered in the literature.

In conclusion, relation is detected between core muscle strength and durability and visual and audio right hand reaction time. It may be stated that development of core muscle strength and durability may improve reaction time. Research of reaction times and core muscle strength and durability of sportsmen from different branches is recommended.

\section{References}

Akgün, N., Ergen, E., \& Ertat, A. (1988). 11-17 Yaşları Arasındaki Çocuklarda Kardiyorespituvar ve Motoscel Fiziksel Uyum Değerleri ve Çeşitli Vücut Ölçümleri ile İlgili Preliminer Sonuçlar. Sporda Yetenek Seçimi Sempozyumu.

Arokoski, J. P., Valta, T., \& Airaksinen, O. et al. (2001). Back and abdominal muscle function during stabilization exercises. Arch Phys. Med Rehabil., 82, 1089-1098. https://doi.org/10.1053/apmr.2001.23819

Aslan, C. S., Karakollukçu, M., Gül, M., \& Fişne, M. (2013). 13-15 yaş güreşçilerin fiziksel ve motorik özelliklerinin bir yıllık değişimlerinin karşılaştırılması. Spor Hekimliği Dergisi, 48, 1-7.

Aslan, C. S., Özer, U., \& Dalkıran, O. (2016) Kız Çocuklarında Koordinasyon ve Reaksiyon Özelliklerinin Yaş Değişkenine Göre İncelenmesi. MAKÜ Săg. Bil. Enst. Derg, 4(1), 27-33.

Barr, K. P., Griggs, M., \& Cadby, T. (2005). Lumbar stabilization: core concepts and current literature, Part 1. Am J Phys Med Rehabil., 84, 473-480. https://doi.org/10.1097/01.phm.0000163709.70471.42

Bassett, S. H., \& Llyod, L. L. (2011). The effect of an eight-week training programme on core stability in junior female elite gymnasts. African Journal for Physical, Health Education, Recreation and Dance (AJPHERD) (Supplement), 9-19. https://doi.org/10.4314/ajpherd.v17i3.68067

Bergmark, A. (1989). Stability of the lumbar spine. A study in mechanical engineering. Acta Orthop Scand Suppl., 230, 1-54. https://doi.org/10.3109/17453678909154177

Bompa, T. O. (1998). Antrenman Kuramı ve Yöntemi. Çeviri: İlknur Keskin, A. Burcu Tuner. Kültür Ofset. Ankara.

Boyac1, A., \& Afyon, Y. A. (2017). The Effect of the Core Training to Physical Performances in Children. Journal of Education and Practice, 8(33), 81-88.

Boyac1, A., \& Tutar, M. (2018). The Effecet of the Quad-Core Training on Core Muscle Strength and Endurance. International Journal of Sports Science, 8(2), 50-54.

Carter, J. M., Beam, W. C., McMahan, S. G. et al. (2006). The effects of stability ball training on spinal stability in sedentary individuals. J Strength Cond Res., 20, 429-435.

Cholewicki, J., Juluru, K., \& McGill, S. M. (1999). Intra-abdominal pressure mechanism for stabilizing the lumbar spine. J Biomech, 32, 13-17. https://doi.org/10.1016/S0021-9290(98)00129-8

Çolakoğlu, H. (1986). Çocuk ve Spor. Milli Eğitim Basımevi, Ankara.

Çolakoğlu, M., Selamoğlu, S., Gündüz, N., Acarbay, Ş., \& Çolakoğlu, S. (1993). Sprint ve Atlayıcıların Hamstring Quadriceps Kuvvet Oranlarının Düzeltilmesinde İzometrik Egzersizlerin Etkileri. Spor Bilimleri Dergisi, 4, 24-31.

Comerford, M. J., \& Mottram, S. L. (2001). Movement and stability dysfunction-contemporary developments. Manual Ther., 6, 15-26. https://doi.org/10.1054/math.2000.0388

Cresswell, A. G., Oddsson, L., \& Thorstensson, A. (1994), The influence of sudden perturbations on trunk muscle activity and intra- abdominal pressure while standing. Exp Brain Res., 98, 336-341. https://doi.org/10.1007/BF00228421

Delignieres, D., Brisswalter, J., \& Legros, P. (1994). Influence of physical exercise on choice reaction time in sport experts: the mediating role of resource allocation. Journal of Human Movement Studies, 27, 173-188.

Di Russo, F., Taddei, F., Apnile, T., \& Spinelli, D. (2006). Neural correlates of fast stimulus discrimination and response selection in top-level fencers, Neurosci Lett., 408(2), 113-118. https://doi.org/10.1016/j.neulet.2006.08.085

Dündar, U. (1996). Antrenman Teorisi. Bağırgan Yayımevi, Sporsal Kuram Dizisi, 3, 133-135, Ankara

Duvan, A., Toros, T., \& Şenel, Ö. (2010). Maksımal yüklenme yoğunluğunun elit türk eskrimcilerin görsel reaksiyon zamanları üzerine etkisi, Niğde Üniversitesi Beden Ĕgitimi ve Spor Bilimleri Dergisi, 4(3), 146-152.

Hewett, T. E., Paterno, M. V., \& Myer, G. D. (2002). Strategies for enhancing proprioception and neuromuscular control 
of the knee. Clin. Orthop. Relat. Res., 402, 76-94. https://doi.org/10.1097/00003086-200209000-00008

Hodges, P. W. (1999). Is there a role for transversus abdominis in lumbo- pelvic stability? Man Ther, 4, 74-86. https://doi.org/10.1054/math.1999.0169

Hodges, P. W., \& Richardson, C. A. (1996). Inefficient muscular stabilization of the lumbar spine associated with low back pain. A motor control evaluation of transversus abdominis. Spine., 21, 2640-2650.

https://doi.org/10.1097/00007632-199611150-00014

Kibler, W. B., Press, J., \& Sciascia, A. (2006). The role of core stability in athletic function. Sport Med., 36, 189-198. https://doi.org/10.2165/00007256-200636030-00001

Kibler, W. B., Sciascia, A., \& Dome, D. (2006). Evaluation of apparent and absolute supraspinatus strength in patients with shoulder injury using the scapular retraction test. Am J Sports Med., 34, 1643-647. https://doi.org/10.1177/0363546506288728

McGill, S. M. (2001). Low back stability: from formal description to issues for performance and rehabilitation. Exerc Sport Sci Rev., 29, 26-31. https://doi.org/10.1097/00003677-200101000-00006

McGill, S. M. (2002), Low Back Stability: Myths and Realities in Low Back Disorders: Evidence Based Prevention and Rehabilitation. Champaign, IL: Human Kinetics.

Nadler, S. F., Malanga, G. A., \& Bartoli, L. A., et al. (2002). Hip muscle imbalance and low back pain in athletes: influence of core strengthening. Med Sci Sports Exerc., 34, 9-16. https://doi.org/10.1097/00005768-200201000-00003

Nadler, S. F., Moley, P., \& Malanga, G. A. et al. (2002). Functional deficits in athletes with a history of low-back pain: a pilot study. Arch Phys Med Rehabil.83:1753-758. https://doi.org/10.1053/apmr.2002.35659

Newmann, D. (2002). Kinesiology of the Musculoskeletal System: Foundations for Physical Rehabilitation. St. Louis: Mosby.

O’Sullivan, P. B., Beales, D. J., \& Beetham, J. A. et al. (2002). Altered motor control strategies in subjects with sacroiliac joint pain during the active straight leg raise test. Spine. 27(1), E1-8. https://doi.org/10.1097/00007632-200201010-00015

Özer, U. (2007). 8-11 Yaş Kız Çocuklarında Mini Tenis Eğitiminin Koordinasyon ve Reaksiyon Zamanı Gelişimi Üzerine Etkisi. Yüksek Lisans Tezi, Cumhuriyet Üniversitesi, Sağllk Bilimleri Enstitüsü, Sivas.

Pulur, A., Ceylan, M. A., \& Karaçam, A. (2017). Üniversitelerarası Şampiyonalara Katılan Bireysel Sporcuların Bazı Fiziksel ve Fizyolojik Özelliklerinin İncelenmesi Atabesbd, 19(1), 7-19.

Putnam, C. (1993). Sequential motions of body segments in striking and throwing skills: descriptions and explanations. J Biomech, 26(suppl 1), 125-135. https://doi.org/10.1016/0021-9290(93)90084-R

Richardson, C. A., Jull, G. A., \& Hodges, P. W. et al. (1999). Therapeutic Exercise for Spinal Segment Stabilization in Low Back Pain: Scientific Basis and Clinical Approach. London: Churchill Livingstone.

Richardson, C. A., Snijders, C. J., \& Hides, J. A. et al. (2002). The relation between the transverse abdominis muscle, sacroiliac joint mechanics and low back pain. Spine. 27, 399-405.

https://doi.org/10.1097/00007632-200202150-00015

Sahrmann, S. A. (2002). Diagnosis and Treatment of Movement Impairment Syndromes. St. Louis: Mosby.

Samson, K. M., \& Sandrey, M. A. (2007). A Core Stabilization Training Program For Tennis Athletes. 41-46. Human Kinetics - ATT IZ(3).

Santana, J. C. (2005). Strength Training for Swimmers:Training the Core Strength and Conditioning Journal, 27(2), 40-42.

Thomas, W. N., \& William, L. L. (2009). The Relationship Between Core Strength And Performance In Division I Female Soccer Players. Official Research Journal of the American Society of Exercise Physiologists, 12(2).

\section{Copyrights}

Copyright for this article is retained by the author(s), with first publication rights granted to the journal.

This is an open-access article distributed under the terms and conditions of the Creative Commons Attribution license which permits unrestricted use, distribution, and reproduction in any medium, provided the original work is properly cited. 